\title{
ANALISIS KADAR PENGAWET NATRIUM BENZOAT PADA PRODUK MINUMAN BERKARBONASI DENGAN METODE HPLC
}

\author{
Rahmawati, Rachmat Kosman, Nurmaya Effendi, Nur Ismayani \\ Fakultas Farmasi Universitas Muslim Indonesia \\ Email : rama.umifarmasi@gmail.com
}

\begin{abstract}
It has been worked a research about the analysis of sodium benzoate content of carbonated beverages which is in Makassar market using High Performance Liquid Chromatography (HPLC) reverse phase. In this research, the analysis was conducted on four brands of carbonated beverages products. The results of analysis are sample $A$ contains $47,6907 \mathrm{mg} / \mathrm{kg}$, sample $B 152,9348 \mathrm{mg} / \mathrm{kg}$, sample $C$ $271,4082 \mathrm{mg} / \mathrm{kg}$, and sample $D 357,3797 \mathrm{mg} / \mathrm{kg}$ of sodium benzoate. The four samples appropriate Permenkes No. 722/Menkes/Per/IX/1988 are <600 mg/kg.
\end{abstract}

Key words : Natrium Benzoate, HPLC, Carbonated Beverages

PENDAHULUAN

Minuman berkarbonasi atau yang dikenal sebagai minuman ringan (softdrink) menjadi salah satu minuman favorit sebagai pelepas dahaga karena rasanya yang enak dan segar (Anneahira, 2013). Karena tersimpan untuk jangka waktu tertentu, maka minuman ini seringkali diberi tambahan pengawet untuk menjaga kualitasnya (Sidik, 2013). Salah satu pengawet yang sering digunakan adalah natrium benzoat. Bentuk garam dari asam benzoat ini lebih disukai penggunaannya karena 200 kali lebih mudah larut daripada bentuk asamnya (Glevitzky, et al., 2009; Dionex, 2004). Food and drug administration (FDA) mengatur penggunaan benzoat sebagai pengawet di USA. FDA memasukkan benzoat sebagai bahan yang secara umum direkomendasikan sebagai GRAS dengan batas maksimum konsentrasi yang diizinkan $0,1 \%$. European Union Legislation menetapkan batas $0,015 \%$ dalam softdrink dan sampai 0m2\% pada produk makanan. Penggunaan benzoat yang lebih tinggi sekitar $0,1 \%$ akan mengubah rasa pada softdrink (Dionex, 2004). Pada komposisi minuman, jelas terlihat adanya kandungan senyawa ini tetapi jumlah yang digunakan seringkali tidak dicantumkan. Hal ini menimbulkan kekhawatiran karena penggunaan 
Analisis Kadar Pengawet Natrium Benzoat Pada Produk Minuman Berkarbonasi Dengan Metode HPLC

yang melebihi batas akan berakibat negatif terhadap kesehatan manusia.

Batas maksimum natrium benzoat untuk minuman ringan adalah 600 $\mathrm{mg} / \mathrm{kg}$ sesuai Permenkes No. 722/Menkes/Per/IX/1988.

Pengawetan makanan dan minuman menggunakan bahan pengawet dibedakan menjadi 3 jenis, yaitu :

a. GRAS (generally recognized as safe), bersifat alami, tidak menimbulkan efek racun pada tubuh.

b. ADI (acceptable daily intake), disesuaikan dengan batas penggunakan hariannya untuk kesehatan konsumen.

c. Pengawet yang tidak layak dikonsumsi (bukan untuk makanan/minuman) seperti boraks dan formalin (Afrianti, 2008).

Syarat umum pengawet yaitu, dapat menghambat pertumbuhan mikroba pembusuk pada pangan baik patogen maupun non patogen, dapat memperpanjang umur simpan pangan, tidak menurunkan kualitas gizi, warna, cita rasa dan bau makanan yang diawetkan (Cahyadi, 2006). Penggunaan natrium benzoat yang melebihi persyaratan dilarang karena senyawa ini terindikasi menyebabkan kerusakan pada DNA, seperti telah dibuktikan oleh Pete Peter yang meneliti pengaruh natrium benzoat pada sel ragi yang ternyata mampu merusak DNA mitokondria pada ragi (Anneahira, 2013).

Asosiasi Konsumen Penang
menyatakan bahwa
(1988) menyatakan bahwa berdasarkan penelitian Badan Pangan Dunia (FAO), konsumsi benzoat yang berlebihan pada tikus dapat menyebabkan kematian dengan gejala hiperaktif, sawan, kencing terusmenerus dan penurunan berat badan (Yuliarti,2007).

Banyak metode analisis yang digunakan untuk menentukan kandungan pengawet dalam makanan atau minuman, tetapi metode High Performanced Liquid Chromatography (HPLC) paling sering digunakan dalam analisis benzoat karena dengan teknik ini, banyak sampel dapat secara sederhana diencerkan dan diinjeksikan secara langsung ke dalam sistem kromatografi tanpa preparasi sampel yang kompleks.

Penelitian ini bertujuan untuk menentukan kadar pengawet natrium benzoat dalam minuman berkarbonasi dengan menggunakan metode High Performance Liquid Chromatography (HPLC) fase terbalik.

$$
\text { Metode HPLC banyak }
$$
digunakan karena resolusinya yang 
Analisis Kadar Pengawet Natrium Benzoat Pada Produk Minuman Berkarbonasi Dengan Metode HPLC

tinggi, selektifitas dan sensitifitas yang sangat baik untuk fase normal maupun fase terbalik (Rohman, 2007).

Pemilihan metode HPLC pada penelitian ini karena metode ini mampu menganalisis sampel dalam jumlah relatif kecil, sampel yang digunakan sedikit, waktu analisis cepat dan sangat baik untuk sampel yang berada dalam bentuk campuran dengan senyawa lain serta dapat dihubungkan dengan detektor yang sesuai (Johnson, 1991).

\section{METODE PENELITIAN}

\section{Waktu dan tempat penelitian}

Penelitian dilaksanakan pada bulan Mei 2013 sampai selesai di Balai Besar Pengawasan Obat dan Makanan (BBPOM) Makassar Sulawesi Selatan bidang pengujian pangan dan bahan berbahaya.

\section{Alat dan bahan penelitian}

Beaker glass $100 \mathrm{~mL}$ (pyrex), Branson ultrasonik, erlenmeyer 250 $\mathrm{mL}$ (pyrex), HPLC (Shimadzu Tipe LC10AT), labu ukur 10, 50, 100, $1000 \mathrm{~mL}$ (pyrex), membran filter diameter 0,45 $\mu \mathrm{m}$, pipet volume 2 dan $5 \mathrm{~mL}$, timbangan analitik.

Air bidestillata, baku standar natrium benzoat, dikalium hidrogen fosfat, kalium dihidrogen fosfat, metanol 60\%, sampel minuman berkarbonasi.

\section{Prosedur penelitian}

\section{Penyiapan sampel}

Sampel berupa 4 merek minuman berkarbonasi diambil dari wilayah kota Makassar. Sebelum dianalisis, sampel terlebih dulu dipreparasi menggunakan branson ultrasonik untuk menghilangkan gelembung gasnya.

\section{Pereaksi yang digunakan :}

1. Fase gerak dapar fosfat : metanol (95:5) : dimasukkan $950 \mathrm{~mL}$ dapar fosfat $\mathrm{pH}$ 6,8 dan $50 \mathrm{~mL}$ metanol $60 \%$ ke dalam labu takar $1000 \mathrm{~mL}$, dihomogenkan.

2. Larutan baku induk : $50,87 \mathrm{mg}$ baku standar natrium benzoat dalam metanol $60 \%$ ad $50 \mathrm{~mL}$ (199,6392 $\mu \mathrm{g} / \mathrm{mL})$.

3. Larutan baku kerja : masingmasing 0,$5 ; 1,0 ; 2,0 ; 3,0 ; 4,0$ dan $5,0 \mathrm{~mL}$ larutan baku induk dalam metanol $60 \%$ ad $50 \mathrm{~mL}$. Larutan disaring dengan membram filter ukuran $\quad 0,45 \quad \mu g \quad$ dan dihampaudarakan (A).

\section{Larutan uji}

Masing-masing sample A, B, C dan $D$ kurang lebih $5 \mathrm{~g}$ dan dimasukkan ke dalam labu ukur 50 $\mathrm{mL}$, ditambakan $5 \mathrm{~mL}$ metanol, ditambahkan air bidestillata sampai batas. Untuk sampel $C$ dan $D$ dipipet berturut-turut 5 dan $2 \mathrm{~mL}$ dari larutan 
Analisis Kadar Pengawet Natrium Benzoat Pada Produk Minuman Berkarbonasi Dengan Metode HPLC

$50 \mathrm{~mL}$, dimasukkan ke dalam labu ukur $10 \mathrm{~mL}$ dan ditambahkan air bidestillata sampai tanda. Lalu masingmasing larutan disaring dengan membran filter ukuran $0,45 \mu \mathrm{m}$ ke dalam tabung reaksi bersumbat dan dihampaudarakan (B). Pengerjaan dilakukan 3 kali unmtuk tiap sampel.

Penetapan kadar

Larutan A dan B masing-masing diinjeksikan ke dalam HPLC dengan kondisi sebagai berikut :
1. Kolom : oktadesilsilana pada partikel silika $5 \mu \mathrm{m}, 4,6 \mathrm{~mm} \times 25$ $\mathrm{cm}$.

2. Fase gerak : dapar fosfat : metanol (95:5), disaring dengan membran filter $0,45 \mu \mathrm{m}$ dan didiamkan.

3. Laju aliran : $1,5 \mathrm{~mL} /$ menit.

4. Detektor : UV, $\lambda 225 \mathrm{~nm}$.

5. Volume penyuntikan : $20 \mu \mathrm{L}$.

\section{HASIL PENELITIAN}

Tabel 1. Hasil pengukuran baku standar natrium benzoat

\begin{tabular}{cccc}
\hline Seri larutan & Konsentrasi $(\mu \mathrm{g} / \mathrm{mL})$ & Waktu retensi (menit) & Area \\
\hline $0,5 \mathrm{~mL} / 50 \mathrm{~mL} \times 199,6392 \mu \mathrm{g} / \mathrm{mL}$ & 1,9963 & 7,072 & 39507 \\
$1,0 \mathrm{~mL} / 50 \mathrm{~mL} \times 199,6392 \mu \mathrm{g} / \mathrm{mL}$ & 3,9927 & 7,060 & 91210 \\
$2,0 \mathrm{~mL} / 50 \mathrm{~mL} \times 199,6392 \mu \mathrm{g} / \mathrm{mL}$ & 7,9855 & 7,057 & 169398 \\
$3,0 \mathrm{~mL} / 50 \mathrm{~mL} \times 199,6392 \mu \mathrm{g} / \mathrm{mL}$ & 11,9783 & 7,061 & 260803 \\
$4,0 \mathrm{~mL} / 50 \mathrm{~mL} \times 199,6392 \mu \mathrm{g} / \mathrm{mL}$ & 15,9711 & 7,053 & 380269 \\
$5,0 \mathrm{~mL} / 50 \mathrm{~mL} \times 199,6392 \mu \mathrm{g} / \mathrm{mL}$ & 19,9639 & 7,056 & 484096 \\
\hline
\end{tabular}

Tabel 2. Hasil identifikasi dan penetapan kadar natrium benzoat dalam sampel A, B, C dan D

\begin{tabular}{|c|c|c|c|c|c|}
\hline Kode sampel & $X(\mu \mathrm{g} / \mathrm{mL})$ & Kadar (mg/kg) & Kadar rata-rata $(\mathrm{mg} / \mathrm{kg})$ & SD & RSD \\
\hline A1 & 5,7149 & 48,2773 & & & \\
\hline A2 & 5,6912 & 48,2213 & 47,6907 & 0,9678 & 2,0293 \\
\hline A3 & 5,759 & 46,5736 & & & \\
\hline B1 & 18,0597 & 152,574 & & & \\
\hline B2 & 18,1041 & 152,8577 & 152,9348 & 0,4048 & 0,2647 \\
\hline B3 & 18,1955 & 153,3727 & & & \\
\hline C1 & 16,0321 & 269,1816 & & & \\
\hline $\mathrm{C} 2$ & 16,2821 & 275,3322 & 271,4082 & 3,4085 & 1,2559 \\
\hline C3 & 15,9414 & 269,4082 & & & \\
\hline D1 & 8,4849 & 358,4156 & & & \\
\hline D2 & 8,3678 & 353,2014 & 357,3797 & 3,7687 & 1,0545 \\
\hline D3 & 8,5894 & 360,5222 & & & \\
\hline
\end{tabular}


Analisis Kadar Pengawet Natrium Benzoat Pada Produk Minuman Berkarbonasi Dengan Metode HPLC

\section{PEMBAHASAN}

Penetapan kadar pengawet natrium benzoat dalam minuman berkarbonasi dilakukan dengan metode HPLC fase terbalik. Fase terbalik (reverse fase) dipilih karena natrium benzoat bersifat polar. Identifikasi natrium benzoat dilakukan dengan membandingkan waktu retensi natrium benzoat dalam sampel dengan waktu retensi baku natrium benzoat. Kadar natrium benzoat dalam sampel diperoleh dengan cara memasukkan luas area sampel yang terukur sebagai variabel $\boldsymbol{y}$ ke dalam persamaan regresi. Persamaan regresi diperoleh dari pembuatan kurva baku natrium benzoat. Dari sini didapatkan nilai untuk koefisien $a$ dan $b$, sedangkan variabel $\boldsymbol{x}$ adalah kadar natrium benzoat dalam sampel yang diukur. Dari kurva baku diperoleh persamaan regreasi $\boldsymbol{y}=24566 x-15845$ seperti pada Gambar 1. Hasil pengukuran HPLC larutan baku standar natrium benzoat terlihat seperti pada Tabel 1.

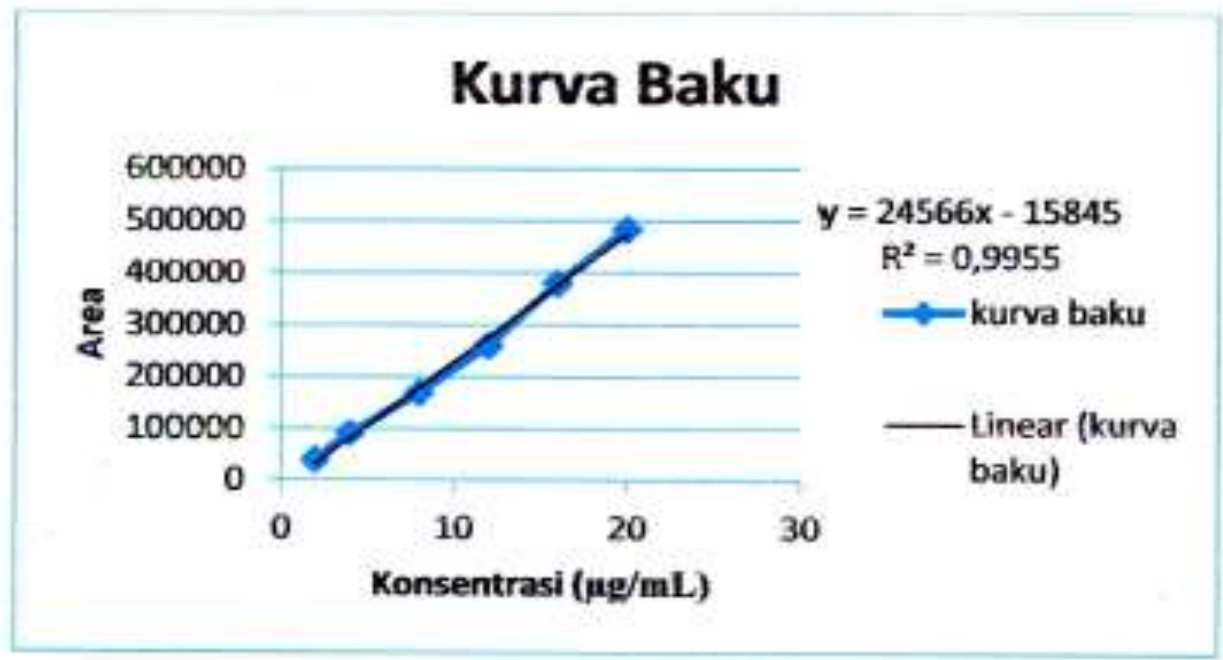

Gambar 1. Kurva baku larutan standar natrium benzoat

Dari persamaan regresi di atas, di atas standar (Tabel 2). dihitunglah nilai $\boldsymbol{x}$ sebagai kadar natrium benzoat dalam sampel seperti KESIMPULAN yang terlihat pada Tabel 2. Dari analisis natrium benzoat dalam sampel, diperoleh nilai RSD yang memenuhi persyaratan, yaitu $\leq 2 \%$ untuk sampel 2, sampel 3 dan sampel 4, sedangkan sampel 1 nilai RSD-nya
Kadar natrium benzoat dalam minuman berkarbonasi berturut-turut adalah 47,6907 mg/kg (sampel A), $152,9348 \mathrm{mg} / \mathrm{kg}$ (sampel B), 271,4082 $\mathrm{mg} / \mathrm{kg}$ (sampel C), and 357,3797 $\mathrm{mg} / \mathrm{kg}$ (sampel D) yang memenuhi persyaratan sesuai Permenkes RI 
Analisis Kadar Pengawet Natrium Benzoat Pada Produk Minuman Berkarbonasi Dengan Metode HPLC

Nomor 722/Menkes/Per/IX/1988, yaitu $600 \mathrm{mg} / \mathrm{kg}$. Nilai RSD yang diperoleh memenuhi syarat, yaitu $\leq 2 \%$ untuk sampel B $(0,2647)$, C $(1,2559)$ dan $D$ $(1,0545)$.

\section{DAFTAR PUSTAKA}

Afrianti, L. H. 2008. Teknologi Pengawetan Pangan. Alfabeta. Bandung.

Anneahira. 2013. Minuman berkolaborasi. (online) http://www.anneahira.com/min uman-berkarbonasi.html, diakses 3 Maret 2013.

Anneahira. 2013. Bahan pengawet minuman buatan - aman atau berbahaya?. (online) http://www.anneahira.com/min uman-berkarbonasi.html, diakses 3 Maret 2013.

Cahyadi. W. 2006. Analisis dan Aspek Kesehatan Bahan Tambahan Pangan, Bumi Aksara. Jakarta.

Dionex, 2004, Determination of benzoate in liquid food products by reagent-free TM ion chromatography,
Application Note 165, Thermo Scientific.

Glevitzky, M., Dumitrel, G. A., Perju, D., Popa, M., 2009, Studies regarding the use of preservatives on soft drinks stability

Johnson. E. L., Robert Stevenson, 1991. Dasar Kromatografi Cair, Terjemahan dari Basic Liquid Chromatography, oleh Padmawinata, Institut Teknologi Bandung, Bandung.

Rohman, A., dan Gandjar, I. G., 2007. Metode Kromatografi untuk Analisis Makanan. Pustaka Pelajar. Yogyakarta.

Rohman, A., dan Gandjar, I. G., 2007. Kimia Farmasi Analisis. Pustaka Pelajar. Yogyakarta.

Sidik, J. M. 2013. Bahan tambahan pangan pada minuman bersoda, amankah?. (online) http://www.antaranews.com.ht $\underline{\mathrm{ml}}$, diakses 13 Maret 2013.

Yuliarti, N. 2007. Awas! Bahaya Di Balik Lezatnya Makanan. Penerbit Andi. Yogyakarta. 